\title{
Temperature Effect on Mechanical Properties and Damage Identification of Concrete Structure
}

\author{
Yubo Jiao, Hanbing Liu, Xianqiang Wang, Yuwei Zhang, Guobao Luo, and Yafeng Gong \\ College of Transportation, Jilin University, Changchun 130025, China \\ Correspondence should be addressed to Yafeng Gong; jlugyf@163.com
}

Received 16 July 2014; Accepted 13 November 2014; Published 25 November 2014

Academic Editor: Peter Majewski

Copyright (C) 2014 Yubo Jiao et al. This is an open access article distributed under the Creative Commons Attribution License, which permits unrestricted use, distribution, and reproduction in any medium, provided the original work is properly cited.

\begin{abstract}
Static and dynamic mechanical properties of concrete are affected by temperature effect in practice. Therefore, it is necessary to investigate the corresponding influence law and mechanism. This paper demonstrates the variation of mechanical properties of concrete at temperatures from $-20^{\circ} \mathrm{C}$ to $60^{\circ} \mathrm{C}$. Temperature effects on cube compressive strength, splitting tensile strength, prism compressive strength, modulus of elasticity, and frequency are conducted and discussed. The results indicate that static mechanical properties such as compressive strength (cube and prism), splitting tensile strength, and modulus of elasticity have highly linear negative correlation with temperature; this law is also applied to the first order frequency of concrete slab. The coupling effect of temperature and damage on change rate of frequency reveals that temperature effect cannot be ignored in damage identification of structure. Mechanism analysis shows that variation of elastic modulus of concrete caused by temperature is the primary reason for the change of frequency.
\end{abstract}

\section{Introduction}

As widely used construction material in civil engineering structures, the properties of concrete have direct relationship with structural safety. Standard concrete specimens are usually cured and tested under ideal conditions according to specifications. However, concrete structures are exposed to external environment in service; the mechanical (static and dynamic) properties of concrete are complicated as they are affected by environmental conditions such as temperature and moisture $[1,2]$.

Numerous researches have been conducted to investigate the relationships between concrete performances and environmental conditions. Peng et al. [3] present environmental investigations to obtain the relationship between explosive spalling occurrence and residual mechanical properties of high-performance concrete and high temperature ranging from 200 to $800^{\circ} \mathrm{C}$. Cülfik and Özturan [4] investigated the temperature effect on mechanical properties of both normal and high strength concrete. Residual compressive and splitting tensile strength, as well as the static modulus of elasticity of specimens, were obtained under elevated temperatures (50, $100,150,200$, and $250^{\circ} \mathrm{C}$ ). The residual mechanical properties started to decrease at $100^{\circ} \mathrm{C}$ for normal strength concrete and high strength concrete performed better under different temperature cycles. Fares et al. [5] conducted an experimental study on performance of self-consolidating concrete under high temperature effect. Mechanical properties such as compressive strength and flexural strength are tested at different temperatures $\left(150,300,450\right.$, and $\left.600^{\circ} \mathrm{C}\right)$. The performance of concrete under transient temperature conditions has been comprehensively investigated, particularly under actions such as high temperatures from fire. However, most of concrete structures are exposed to external temperature between $-20^{\circ} \mathrm{C}$ and $60^{\circ} \mathrm{C}$ in practical situation; relative little literature is available for properties of concrete under this condition. Shoukry et al. [6] investigated static mechanical properties of concrete under temperature ranging from $-20^{\circ} \mathrm{C}$ to $50^{\circ} \mathrm{C}$ and relative humidity between $40 \%$ and $60 \%$. The results indicated that concrete strength in compression, tension, and corresponding modulus of elasticity decreased with temperature increasing. However, the dynamic properties of concrete structure are not investigated.

Dynamic-based methods have been widely applied for health monitoring and damage identification of structures 
TABLE 1: Mixture proportions.

\begin{tabular}{lcc}
\hline Materials & & Nominal proportions \\
\hline Cement & $\left(\mathrm{kg} / \mathrm{m}^{3}\right)$ & 336 \\
Coarse aggregate & $\left(\mathrm{kg} / \mathrm{m}^{3}\right)$ & 1221 \\
Fine aggregate & $\left(\mathrm{kg} / \mathrm{m}^{3}\right)$ & 658 \\
Water & $\left(\mathrm{kg} / \mathrm{m}^{3}\right)$ & 185 \\
Water/cement ratio & & 0.55 \\
\hline
\end{tabular}

[7-9], because the dynamic properties (frequency, mode shape, and damping) are closely related to structural parameters such as stiffness and mass [10-12]. At present, most researches are focused on the effect of damage on dynamic properties without considering temperature effect [13]. However, if the effects are not rationally taken into account and removed, the damage identification results cannot be reliable. Farrar et al. [14] present the monitoring results of Alamosa Canyon Bridge. They found that the first eigenfrequency of the structure varies approximately $5 \%$ over a 24 -hour time period. Askegaard and Mossing [15] found that the variation of frequency for a three-span footbridge was $10 \%$ over the year. Wahab and de Roeck [16] observed a change of 4\% $5 \%$ in natural frequencies of a prestressed concrete bridge in spring and winter from dynamic test. Moser and Moaveni [17] demonstrated that significant variability in natural frequencies was identified from a continuous monitoring system installed on Dowling Hall Footbridge, and these changes in natural frequencies are strongly correlated with temperature. Extensive research results reveal that temperature will lead to frequencies changes of structure, but explicit investigation of the effect of temperature is not obtained in experiments.

In this paper, static mechanical properties such as cube compressive strength, split tensile strength, prism compressive strength, and modulus of elasticity of concrete are conducted under different temperatures from $-20^{\circ} \mathrm{C}$ to $60^{\circ} \mathrm{C}$. The relationships between properties and temperatures are determined. Meanwhile, the temperature effect on first order natural frequency of concrete slab is also observed and corresponding influence mechanism is discussed.

\section{Experimental Details}

2.1. Materials and Mixtures. PO 42.5 type Portland cement confirming the requirements of GB175-2007 [18] is used in this study. Crushed stone with diameters ranging from $5 \mathrm{~mm}$ to $20 \mathrm{~mm}$ and natural sand with fineness modulus of 2.7 are adopted as coarse and fine aggregates, respectively. The mixture proportions of concrete are listed in Table 1. These ingredients are mixed for about $4 \mathrm{~min}$. Slump results of concrete are tested with $38 \mathrm{~mm}$, which indicate that the mixture is with favorable cohesiveness and meets the requirements of GB/T 50081-2002 [19] and GB 50164-2011 [20].

2.2. Specimens. Concrete specimens are $150 \mathrm{~mm}$ cubes (produced for testing cube compressive strength and splitting tensile strength) and $150 \mathrm{~mm} \times 150 \mathrm{~mm} \times 300 \mathrm{~mm}$ prisms (produced for testing prism compressive strength and

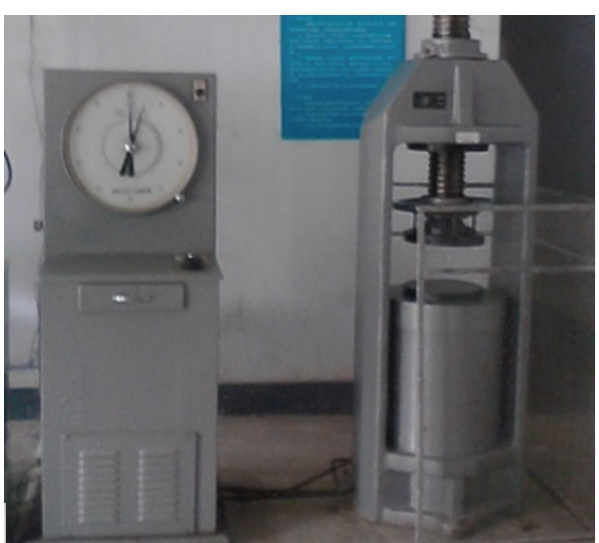

FIGURE 1: Compression testing machine $1(2000 \mathrm{kN})$.

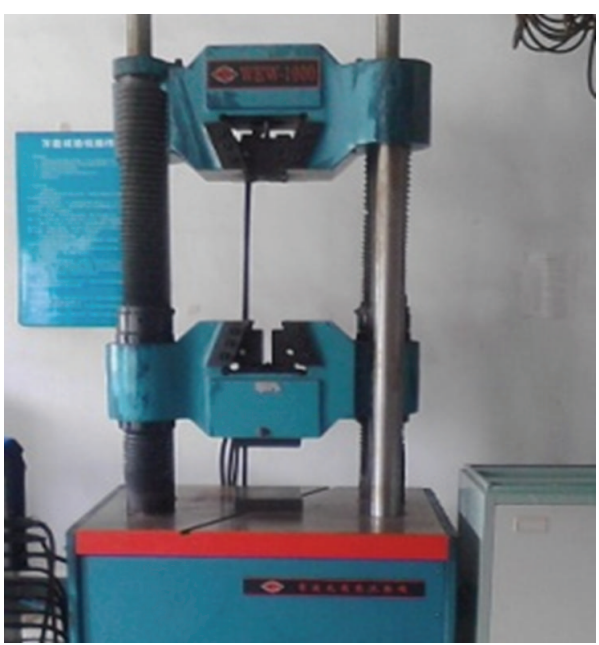

FIgURE 2: Compression testing machine $2(1000 \mathrm{kN})$.

modulus of elasticity) which are casted horizontally in steel molds and compacted by vibrating machine. All specimens are removed from the molds $24 \mathrm{~h}$ after casting and cured in a curing room $\left(20 \pm 3^{\circ} \mathrm{C}\right.$ and $95 \% \mathrm{RH}$ (relative humidity) for 28 days (GB/T 50082-2009) [21].

Slabs with length $60 \mathrm{~cm}$, width $15 \mathrm{~cm}$, and height $5 \mathrm{~cm}$ are also prefabricated, and they are also cured in a curing room $\left(20 \pm 3^{\circ} \mathrm{C}\right.$ and $95 \% \mathrm{RH}$ (relative humidity)) for 28 days.

2.3. Testing Machines. Two different compression testing machines are used to obtain the static properties of concrete. Both cube and prism compressive strength and modulus of elasticity are tested through machine 1 (shown in Figure 1) with maximum load $2000 \mathrm{kN}$. Splitting tensile strength is measured by machine 2 (shown in Figure 2) with maximum load $1000 \mathrm{kN}$, which can realize the dynamic monitoring of force and output the force-displacement curves.

The temperatures are jointly controlled by refrigerator and oven. The former is used for $-50^{\circ} \mathrm{C}-0^{\circ} \mathrm{C}$, while the latter is for $20^{\circ} \mathrm{C}-300^{\circ} \mathrm{C}$.

Piezoelectric acceleration sensor is applied for measuring acceleration response signals for slabs, and DH 5920 type 

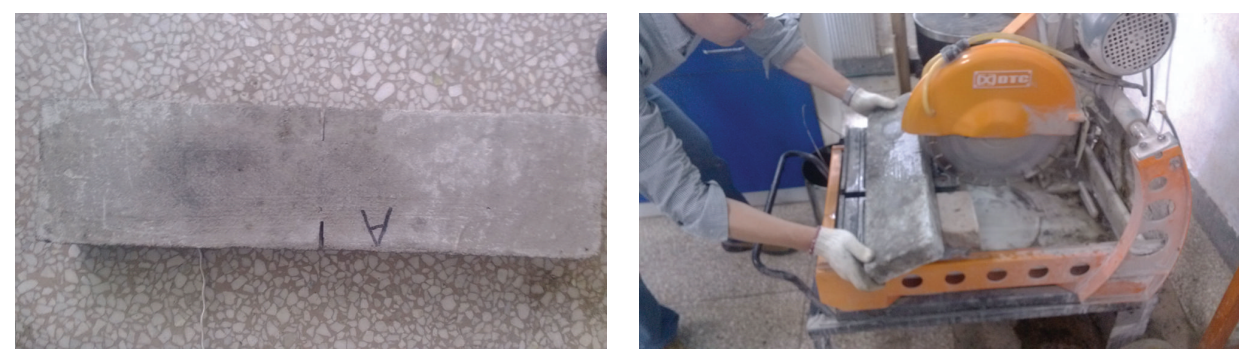

FIgURe 3: Damage simulation of slab using cutting machine.

dynamic signal measurement system is used to obtain the natural frequency from the measured signals.

As for the damage of slab, it is achieved by cutting machine (shown in Figure 3).

2.4. Testing Procedures. The cube compressive strength, splitting tensile strength, prism compressive strength, modulus of elasticity, and frequency of concrete structures are tested under temperatures $-20^{\circ} \mathrm{C}, 0^{\circ} \mathrm{C}, 20^{\circ} \mathrm{C}, 40^{\circ} \mathrm{C}$, and $60^{\circ} \mathrm{C}$. In order to eliminate the influence of moisture, the concrete specimens are wrapped by preservative film to maintain humidity stability. Each specimen is placed in temperature control apparatus for $4 \mathrm{~h}$ to make the core temperature of concrete consistent with environmental temperature before testing.

2.4.1. Cube Compressive Strength. Totally fifteen $150 \mathrm{~mm} \times$ $150 \mathrm{~mm} \times 150 \mathrm{~mm}$ specimens are tested for calculating the cube compressive strength (i.e., three specimens at each temperature). In the process of cube compressive strength testing, machine 1 imposes loads at the speed of $0.5-0.8 \mathrm{MPa} / \mathrm{s}$ [19]. The loads are recorded until the failure of specimens. The cube compressive strength of each specimen can be calculated by

$$
f_{\mathrm{cu}}^{i}=\frac{F_{\mathrm{cu}}^{i}}{A_{\mathrm{cu}}^{i}},
$$

where $f_{\mathrm{cu}}^{i}$ is cube compressive strength of the $i$ th concrete specimen, $F_{\mathrm{cu}}^{i}$ is the corresponding failure load under compression, $A_{\text {cu }}^{i}$ is bearing area of specimens, and $i=1,2,3$ in this paper.

The final cube compressive strength $f_{\text {cu }}$ of concrete can be determined by the following regulations [19].

(1) The average value of cube compressive strength for three specimens is treated as final compressive strength.

(2) If one of maximum and minimum value of cube compressive strength for three specimens exceeds the medium one by $15 \%$, the medium value of cube compressive strength is used as final cube compressive strength.

(3) If all of maximum and minimum values of cube compressive strength for three specimens exceed the medium one by $15 \%$, the results are considered to be invalid and another group of specimens should be retested.

2.4.2. Splitting Tensile Strength. Another fifteen $150 \mathrm{~mm} \times$ $150 \mathrm{~mm} \times 150 \mathrm{~mm}$ specimens are measured for calculating the splitting tensile strength (i.e., three specimens at each temperature). In the process of splitting tensile strength testing, machine 2 applied loads at the speed of $0.05-$ $0.08 \mathrm{MPa} / \mathrm{s}$ [19] until the failure of specimens. The splitting tensile strength of concrete can be obtained by

$$
f_{\mathrm{ts}}^{i}=\frac{2 F_{\mathrm{ts}}^{i}}{\left(\pi \times A_{\mathrm{ts}}^{i}\right)},
$$

where $f_{\mathrm{ts}}^{i}$ is splitting tensile strength of the $i$ th concrete specimen, $F_{\mathrm{ts}}^{i}$ is the corresponding failure load under splitting, and $A_{\mathrm{ts}}^{i}$ is splitting area of specimens.

Final splitting tensile strength $f_{\text {ts }}$ can be calculated according to the same rules of getting $f_{\mathrm{cu}}$.

2.4.3. Prism Compressive Strength. Totally fifteen $150 \mathrm{~mm} \times$ $150 \mathrm{~mm} \times 300 \mathrm{~mm}$ prisms are tested for measuring the prism compressive strength of concrete. In the process of prism compressive strength testing, machine 1 imposes loads at the speed of $0.5-0.8 \mathrm{MPa} / \mathrm{s}$ [19]. The loads are recorded until the failure of specimens. The prism compressive strength of each specimen can be calculated by

$$
f_{\mathrm{cp}}^{i}=\frac{F_{\mathrm{cp}}^{i}}{A_{\mathrm{cp}}^{i}},
$$

where $f_{\mathrm{cp}}^{i}$ is prism compressive strength of the $i$ th concrete specimen, $F_{\mathrm{cp}}^{i}$ is the corresponding failure load under compression, $A_{\mathrm{cp}}^{i}$ is bearing area of specimens, and $i=1,2,3$ in this paper.

Final prism compressive strength $f_{\mathrm{cp}}$ can be calculated according to the same rules of getting $f_{\mathrm{cu}}$.

2.4.4. Modulus of Elasticity. Totally fifteen $150 \mathrm{~mm} \times 150 \mathrm{~mm}$ $\times 300 \mathrm{~mm}$ prisms are tested for calculating the modulus of elasticity; it can be calculated by

$$
E_{c}^{i}=\frac{F_{a}^{i}-F_{0}^{i}}{A_{e}^{i}} \times \frac{L}{\Delta d^{i}},
$$


where $E_{c}^{i}$ is modulus of elasticity of the $i$ th concrete specimen; $F_{a}^{i}$ and $F_{0}^{i}$ are loads corresponding to the stress of one-third prism compressive strength and $0.5 \mathrm{MPa}$, respectively; $L$ is gauge length of specimen, $L=150 \mathrm{~mm}$ in this paper; $\Delta d^{i}$ is average value of deformation for concrete from $F_{o}$ to $F_{a}$, and it can be obtained by

$$
\Delta d^{i}=\varepsilon_{a}^{i}-\varepsilon_{0}^{i},
$$

where $\varepsilon_{a}^{i}$ is the average value of deformation for concrete specimens under $F_{a}^{i}$ and $\varepsilon_{0}^{i}$ is the average value of deformation for concrete specimens under $F_{0}^{i} \cdot \varepsilon_{a}^{i}$ and $\varepsilon_{0}^{i}$ are tested through dial gauges.

Final modulus of elasticity $E_{c}$ can be calculated according to GB/T 50081-2002 [19].

2.4.5. Frequency and Damage Identification. Three concrete slabs are prefabricated and tested for frequency under temperatures $-20^{\circ} \mathrm{C}, 0^{\circ} \mathrm{C}, 20^{\circ} \mathrm{C}, 40^{\circ} \mathrm{C}$, and $60^{\circ} \mathrm{C}$. The concrete slabs are also wrapped by preservative film to maintain humidity stability to eliminate the influence of moisture. Firstly, the slabs are measured under intact condition and temperature effect on frequency for undamaged slab is discussed. Secondly, the midspan sections of slabs are cut by special machine to simulate damage. Damage severity is represented by cutting depth; it can be calculated by

$$
\delta=\frac{W_{c}}{W} \times 100 \%,
$$

where $\delta$ is damage severity and $W_{c}$ and $W$ are widths of damaged and intact midspan sections, respectively.

\section{Static Mechanical Properties}

3.1. Cube Compressive and Splitting Tensile Strength. The testing arrangements of cube compressive and splitting tensile strength are shown in Figures 4 and 5, respectively.

The testing results of concrete under different temperatures are listed in Table 2. The relationship between cube compressive strength, splitting tensile strength, and temperatures is shown in Figures 6 and 7.

Linear formulas are applied to simulate the relationship between cube compressive strength, splitting tensile strength, and temperature. They are listed in the following equations, respectively:

$$
\begin{gathered}
f_{\mathrm{cu}}=-0.348 \mathrm{~T}+45.89, \\
R^{2}=0.9541 \quad\left(-20^{\circ} \mathrm{C} \leq \mathrm{T} \leq 60^{\circ} \mathrm{C}\right), \\
f_{\mathrm{ts}}=-0.041 \mathrm{~T}+4.750, \\
R^{2}=0.9545 \quad\left(-20^{\circ} \mathrm{C} \leq \mathrm{T} \leq 60^{\circ} \mathrm{C}\right) .
\end{gathered}
$$

As can be seen from Figures 6 and 7 and Table 2, the cube compressive strength and splitting tensile strength both decrease with the increasing of temperature. The cube compressive strength improves by $100.3 \%$ from $60^{\circ} \mathrm{C}$ to $-20^{\circ} \mathrm{C}$, while it is $132.9 \%$ for splitting tensile strength.

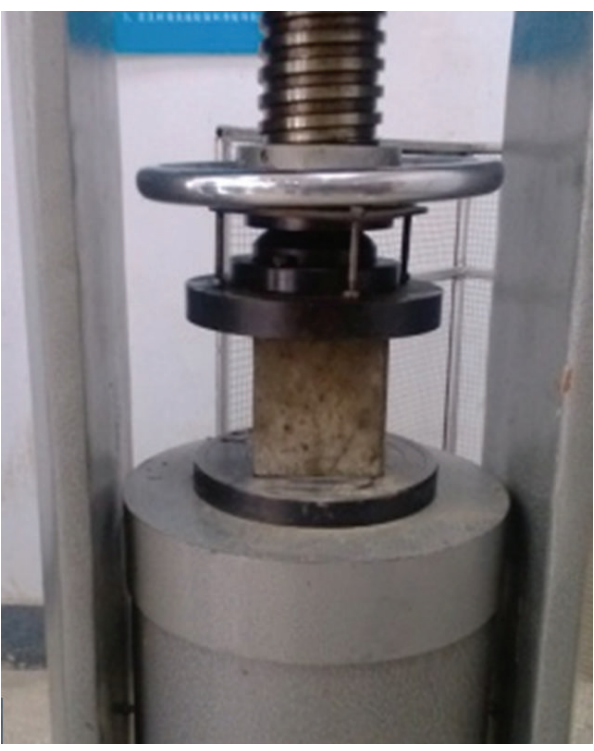

FIgURE 4: Compression test.

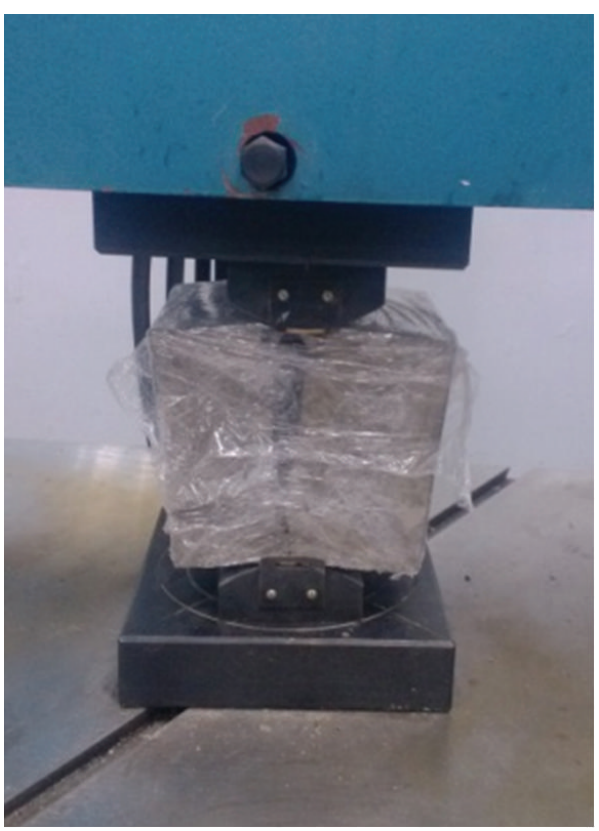

FIGURE 5: Splitting tensile test.

3.2. Prism Compressive Strength and Modulus of Elasticity. Prism compressive strengths of specimens under temperatures $-20^{\circ} \mathrm{C}, 0^{\circ} \mathrm{C}, 20^{\circ} \mathrm{C}, 40^{\circ} \mathrm{C}$, and $60^{\circ} \mathrm{C}$ are measured and calculated. The results are listed in Table 3 and Figure 8.

The relationship between prism compressive strength and temperature is listed in

$$
\begin{gathered}
f_{\mathrm{cp}}=-0.209 \mathrm{~T}+34.90, \\
R^{2}=0.9593 \quad\left(-20^{\circ} \mathrm{C} \leq \mathrm{T} \leq 60^{\circ} \mathrm{C}\right) .
\end{gathered}
$$

The relationship reveals that prism compressive strength decreases with the increasing of temperature and presents 
TABLE 2: Results of cube compressive strength and splitting tensile strength for concrete under different temperatures.

\begin{tabular}{|c|c|c|c|c|c|c|}
\hline Temperature $\left({ }^{\circ} \mathrm{C}\right)$ & $F_{\mathrm{cu}}^{i}(\mathrm{kN})$ & $f_{\mathrm{cu}}^{i}(\mathrm{MPa})$ & $F_{\mathrm{ts}}^{i}(\mathrm{kN})$ & $f_{\mathrm{ts}}^{i}(\mathrm{MPa})$ & $f_{\mathrm{cu}}(\mathrm{MPa})$ & $f_{\mathrm{ts}}(\mathrm{MPa})$ \\
\hline \multirow{3}{*}{-20} & 1264 & 56.18 & 238 & 6.738 & \multirow{3}{*}{53.75} & \multirow{3}{*}{5.889} \\
\hline & 1244 & 55.29 & 208 & 5.889 & & \\
\hline & 1120 & 49.78 & 168 & 4.756 & & \\
\hline \multirow{3}{*}{0} & 980 & 43.56 & 164 & 4.643 & \multirow{3}{*}{44.33} & \multirow{3}{*}{4.454} \\
\hline & 1020 & 45.33 & 156 & 4.417 & & \\
\hline & 992 & 44.09 & 152 & 4.303 & & \\
\hline \multirow{3}{*}{20} & 940 & 41.78 & 140 & 3.964 & \multirow{3}{*}{41.18} & \multirow{3}{*}{3.888} \\
\hline & 910 & 40.44 & 134 & 3.794 & & \\
\hline & 930 & 41.33 & 138 & 3.907 & & \\
\hline \multirow{3}{*}{40} & 660 & 29.33 & 98 & 2.774 & \multirow{3}{*}{28.56} & \multirow{3}{*}{2.812} \\
\hline & 648 & 28.80 & 96 & 2.718 & & \\
\hline & 620 & 27.56 & 104 & 2.944 & & \\
\hline \multirow{3}{*}{60} & 624 & 27.73 & 80 & 2.265 & \multirow{3}{*}{26.84} & \multirow{3}{*}{2.529} \\
\hline & 600 & 26.67 & 100 & 2.831 & & \\
\hline & 588 & 26.13 & 88 & 2.491 & & \\
\hline
\end{tabular}

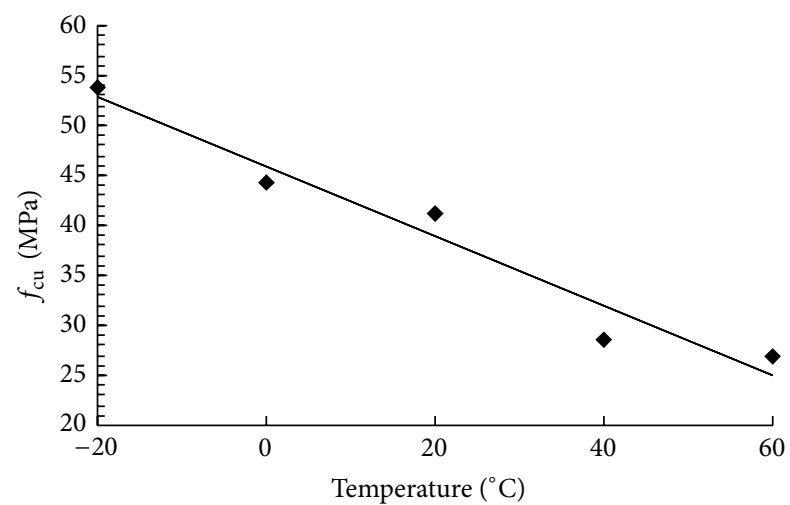

FIGURE 6: Temperature effect on cube compressive strength of concrete.

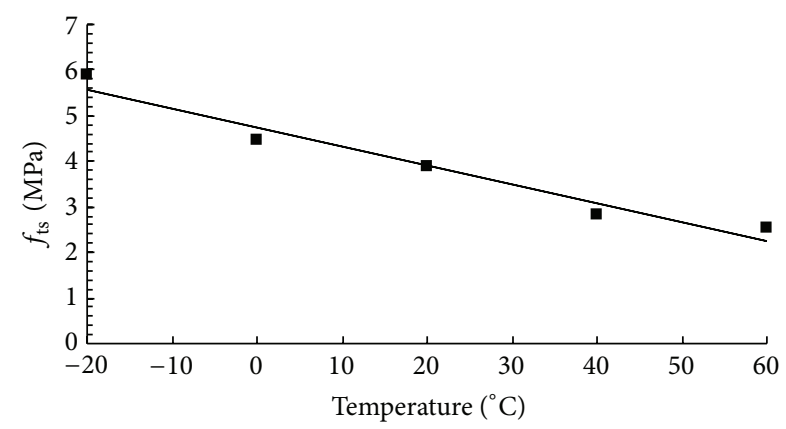

Figure 7: Temperature effect on splitting tensile strength of concrete.

linear character. The prism strength decreases by $70.76 \%$ from $-20^{\circ} \mathrm{C}$ to $60^{\circ} \mathrm{C}$.

The testing arrangements of modulus of elasticity are shown in Figure 9.
TABLE 3: Results of prism compressive strength for concrete under different temperatures.

\begin{tabular}{lccc}
\hline Temperature $\left({ }^{\circ} \mathrm{C}\right)$ & $F_{\mathrm{cp}}^{i}(\mathrm{~N})$ & $f_{\mathrm{cp}}^{i}(\mathrm{MPa})$ & $f_{\mathrm{cp}}(\mathrm{MPa})$ \\
\hline \multirow{3}{*}{-20} & 904 & 40.18 & \\
& 864 & 38.40 & 40.47 \\
& 964 & 42.84 & \\
\hline \multirow{2}{*}{0} & 780 & 34.67 & \\
& 760 & 33.78 & 34.43 \\
\hline \multirow{2}{*}{20} & 784 & 34.84 & \\
& 626 & 27.82 & \\
\hline \multirow{3}{*}{40} & 682 & 30.31 & 28.92 \\
& 644 & 28.62 & \\
\hline \multirow{2}{*}{60} & 572 & 25.42 & \\
& 585 & 26.00 & 26.00 \\
& 598 & 26.58 & \\
\hline
\end{tabular}

The measurement results and temperature effects on modulus of elasticity are listed in Table 4 and Figure 10.

Regression analysis is conducted through linear formula to represent the relationship between modulus of elasticity and temperature; it is listed in

$$
\begin{gathered}
E_{c}=-0.125 T+29.13, \\
R^{2}=0.9852 \quad\left(-20^{\circ} \mathrm{C} \leq T \leq 60^{\circ} \mathrm{C}\right) .
\end{gathered}
$$

From Table 4 and Figure 10, modulus of elasticity increases with the decreasing of temperature, and a good linear relationship is presented. The modulus of elasticity improves by $48.3 \%$ from $60^{\circ} \mathrm{C}$ to $-20^{\circ} \mathrm{C}$. 


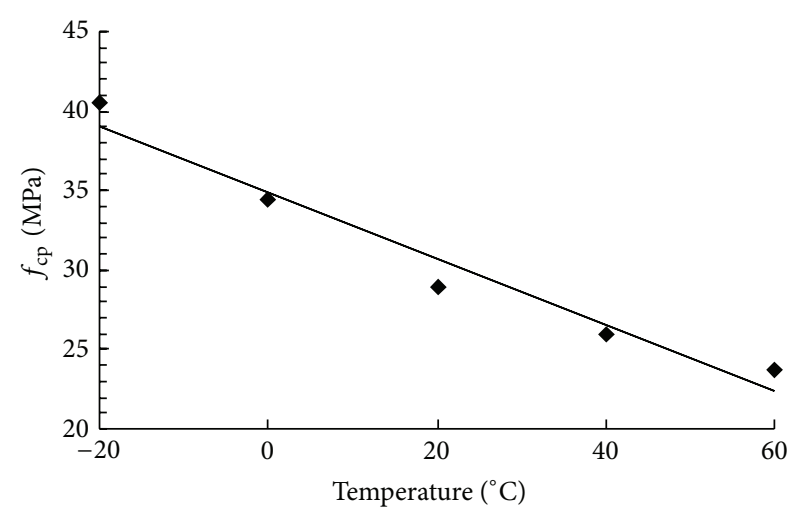

FIGURE 8: Temperature effect on prism compressive strength.

TABLE 4: Modulus of elasticity for concrete under different temperatures.

\begin{tabular}{lccccc}
\hline $\begin{array}{l}\text { Temperature } \\
\left({ }^{\circ} \mathrm{C}\right)\end{array}$ & $F_{0}(\mathrm{kN})$ & $F_{a}(\mathrm{kN})$ & $\Delta d(\mathrm{~mm})$ & $E_{c}^{i}(\mathrm{GPa})$ & $E_{c}(\mathrm{GPa})$ \\
\hline \multirow{3}{*}{-20} & 11.52 & 245.01 & 0.050 & 31.132 & \\
& 11.30 & 245.90 & 0.048 & 32.583 & 31.928 \\
& 11.70 & 247.40 & 0.049 & 32.067 & \\
\hline \multirow{3}{*}{0} & 12.24 & 249.35 & 0.045 & 35.127 & \\
& 11.50 & 245.80 & 0.061 & 25.607 & 28.397 \\
& 11.70 & 246.50 & 0.064 & 24.458 & \\
20 & 12.87 & 244.68 & 0.057 & 27.112 & \\
& 10.90 & 245.32 & 0.059 & 26.488 & 27.184 \\
& 11.60 & 242.21 & 0.055 & 27.953 & \\
40 & 11.40 & 245.50 & 0.065 & 24.010 & \\
& 11.30 & 245.60 & 0.069 & 22.638 & 24.091 \\
& 18.14 & 252.60 & 0.061 & 25.624 & \\
\hline \multirow{3}{*}{60} & 11.80 & 243.77 & 0.067 & 23.082 & \\
& 11.80 & 244.90 & 0.068 & 22.853 & 21.533 \\
& 16.21 & 262.60 & 0.088 & 18.666 & \\
\hline
\end{tabular}

TABLE 5: First order natural frequency for intact concrete slab.

\begin{tabular}{lccc}
\hline $\begin{array}{l}\text { Temperature } \\
\left({ }^{\circ} \mathrm{C}\right)\end{array}$ & $A$ & Slabs & $C$ \\
\hline-20 & 201.66 & 201.66 & 196.77 \\
0 & 192.38 & 196.77 & 193.85 \\
20 & 189.94 & 192.38 & 186.53 \\
40 & 184.28 & 189.91 & 182.99 \\
60 & 178.22 & 187.01 & 173.83 \\
\hline
\end{tabular}

\section{Frequency and Damage Identification of Slab}

4.1. Temperature Effect on Frequency. The test process is illustrated in Figure 11. Testing results of first order natural frequency for three slabs $(A, B$, and $C)$ are listed in Table 5.

Temperature effect on frequency of slabs is also demonstrated in Figure 12. It can be concluded that the influence
TABLE 6: The first order natural frequencies under coupling effect of temperature and damage $(\mathrm{Hz})$.

\begin{tabular}{lccccc}
\hline $\begin{array}{l}\text { Damage } \\
\text { severity (\%) }\end{array}$ & -20 & 0 & 20 & 40 & 60 \\
\hline 0 & 201.655 & 192.380 & 189.935 & 184.280 & 178.220 \\
10 & 195.800 & 188.925 & 180.170 & 176.265 & 172.360 \\
20 & 183.185 & 177.245 & 174.800 & 172.850 & 166.985 \\
30 & 177.240 & 173.335 & 169.915 & 164.050 & 158.685 \\
40 & 173.335 & 169.355 & 165.075 & 160.905 & 156.000 \\
\hline
\end{tabular}

of temperature on first order frequency is obvious. The frequency decreases with the increasing of temperature, and it shows clear negative correlation.

4.2. Temperature Effect on Damage Identification. The results of slab $A$ are used as examples to investigate the variation of frequency under the integrated effect of temperature and damage. Five damage severities including $0 \%$ (undamaged), $10 \%, 20 \%, 30 \%$, and $40 \%$ are simulated, and the measurement results are listed in Table 6 and Figure 13.

As can be seen from Table 6 and Figure 13, the first order natural frequency decreases with the increasing of damage severity under the same temperature, while it decreases with the increasing of temperature under the same damage severity.

In damage identification of structures, change rate of natural frequency is an effective damage indicator. According to dynamic theory, damage of structure will lead to the reduction of frequencies. In order to illustrate the effect of temperature in damage identification of concrete slab, the baseline natural frequency of undamaged structure is assumed to be measured under temperature $40^{\circ} \mathrm{C}$, and the damaged ones are tested under temperatures $-20^{\circ} \mathrm{C}, 0^{\circ} \mathrm{C}, 20^{\circ} \mathrm{C}, 40^{\circ} \mathrm{C}$, and $60^{\circ} \mathrm{C}$. The corresponding change rates of first order frequency are calculated by (10), and the results are listed in Table 7 and Figure 14. Consider

$$
\alpha_{\delta}^{T}=\frac{f_{\delta}^{T}-f_{\delta}^{40}}{f_{\delta}^{40}} \times 100 \%,
$$

where $f$ is the measured first order natural frequency, $\alpha$ is the change rate of frequency, $\delta$ is damage severity $(\delta=0 \%$, $10 \%, 20 \%, 30 \%$, and $40 \%)$, and $T$ is testing temperature $(T=$ $-20^{\circ} \mathrm{C}, 0^{\circ} \mathrm{C}, 20^{\circ} \mathrm{C}, 40^{\circ} \mathrm{C}$, and $60^{\circ} \mathrm{C}$ ).

In theory, damage of structure will lead to the reduction of frequency. Therefore, the change rate of frequency is a negative value. However, the change rates of frequency for damage severity $10 \%$ at temperatures $-20^{\circ} \mathrm{C}$ and $0^{\circ} \mathrm{C}$ are positive. Reasons for this phenomenon lie in the fact that frequencies increase from temperature $40^{\circ} \mathrm{C}$ to $-20^{\circ} \mathrm{C}$ and $0^{\circ} \mathrm{C}$, and the recruitments due to temperatures are greater than the decreasing value caused by damage. It reveals that frequency changes caused by damage have been submerged by temperature effect, and damage identification results will be unreliable in practice. The range analysis is also conducted and 


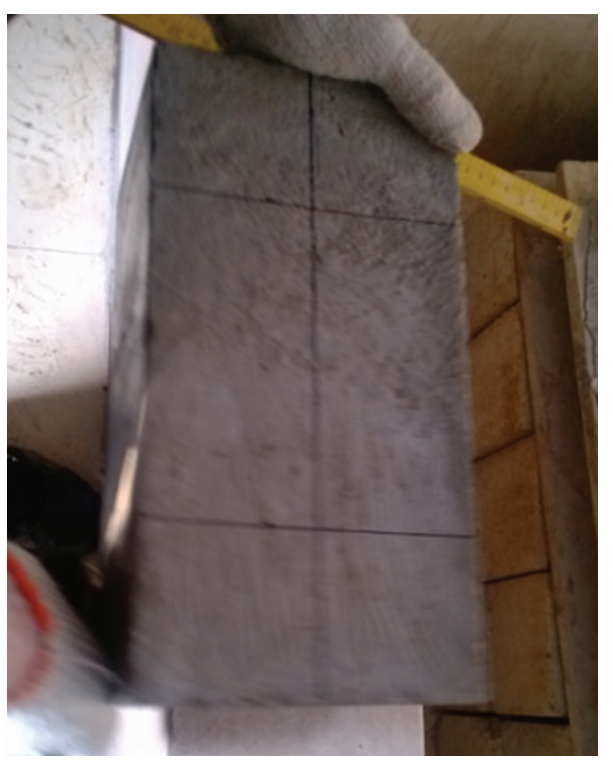

(a) Gauge length

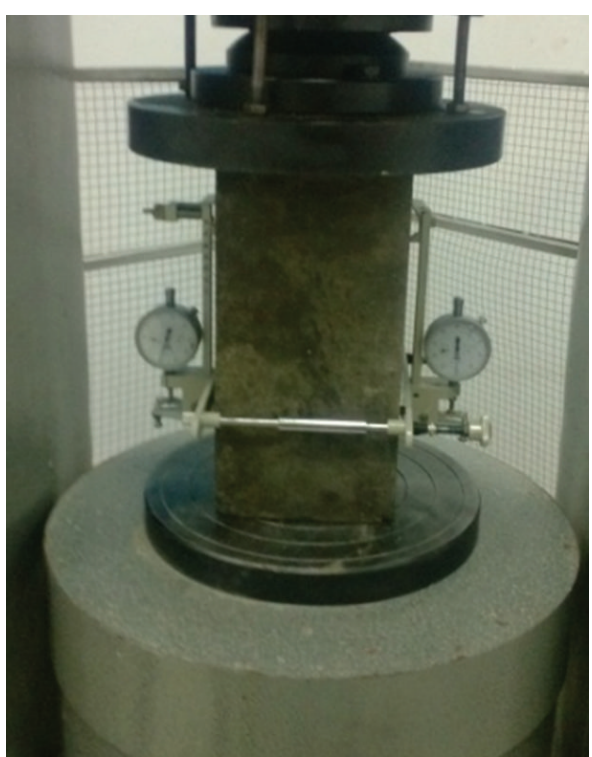

(b) Modulus of elasticity test

FIGURE 9: Testing arrangement of modulus of elasticity.

TABLE 7: Change rate of the first order natural frequency (\%).

\begin{tabular}{lcccccc}
\hline \multirow{2}{*}{ Damage severity (\%) } & \multicolumn{5}{c}{ Temperature $\left({ }^{\circ} \mathrm{C}\right)$} \\
& -20 & 0 & 20 & 40 & 60 & Range caused by temperature \\
\hline 0 & 9.429 & 4.395 & 3.069 & 0.000 & -3.288 & $\mathbf{1 2 . 7 1 7}$ \\
10 & 6.251 & 2.521 & -2.230 & -4.349 & -6.468 & $\mathbf{1 2 . 7 1 9}$ \\
20 & -0.594 & -3.818 & -5.144 & -6.203 & -9.385 & $\mathbf{8 . 7 9 1}$ \\
30 & -3.820 & -5.939 & -7.795 & -10.978 & -13.889 & $\mathbf{1 0 . 0 6 9}$ \\
40 & -5.939 & -8.099 & -10.422 & -12.685 & -15.346 & $\mathbf{9 . 4 0 7}$ \\
Range caused by damage & $\mathbf{1 5 . 3 6 8}$ & $\mathbf{1 2 . 4 9 4}$ & $\mathbf{1 3 . 4 9 1}$ & $\mathbf{1 2 . 6 8 5}$ & $\mathbf{1 2 . 0 5 8}$ & \\
\hline
\end{tabular}

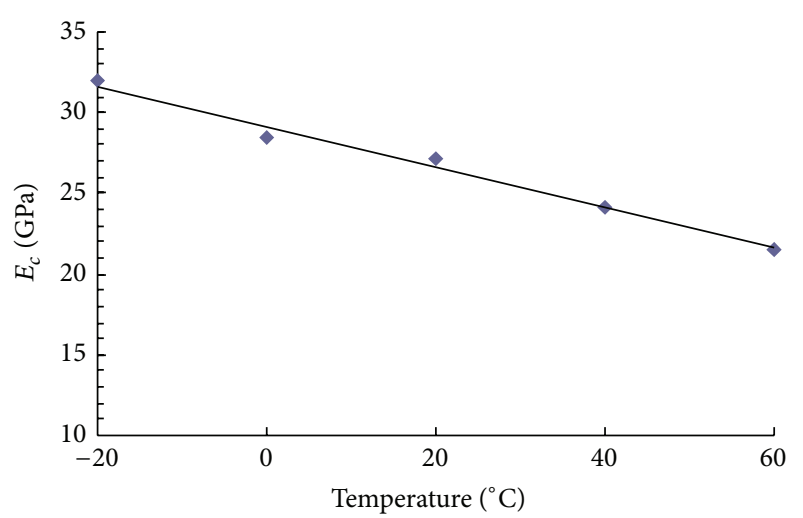

FIgURE 10: Temperature effect on modulus of elasticity.

listed in Table 7. As can be seen from this table, the maximum range caused by damage is $15.368 \%$, while it is $12.720 \%$ for temperature. The temperature effect is not negligible.

4.3. Mechanism Analysis. For a simply supported uniform beam with length $l$, height $h$, density $\rho$, and modulus of
TABLE 8: Theoretical and measured results of the first order frequency for concrete slab.

\begin{tabular}{lccc}
\hline $\begin{array}{l}\text { Temperature } \\
\left({ }^{\circ} \mathrm{C}\right)\end{array}$ & $E(\mathrm{GPa})$ & $\begin{array}{c}\text { Theoretical } \\
\text { results }(\mathrm{Hz})\end{array}$ & $\begin{array}{c}\text { Measured } \\
\text { results }(\mathrm{Hz})\end{array}$ \\
\hline-20 & 31.928 & 224.95 & 201.66 \\
0 & 28.397 & 212.15 & 192.38 \\
20 & 27.184 & 207.57 & 189.94 \\
40 & 24.091 & 195.40 & 184.28 \\
60 & 21.533 & 184.74 & 178.22 \\
\hline
\end{tabular}

elasticity $E$, the undamped flexural vibration frequency of order $n$ can be calculated by [22-24]

$$
f_{n}=\frac{n^{2} \pi h}{2 l^{2}} \sqrt{\frac{E}{12 \rho}}
$$

Temperature effect on modulus of elasticity has been tested and listed in Table 8 . Theoretical calculation results of the first order frequency can be obtained based on (11); they are shown in Table 8 and Figure 15. 


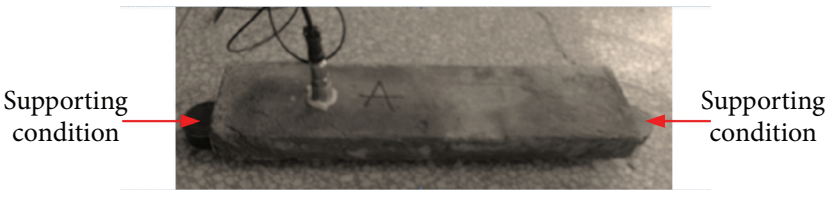

(a) Concrete slab

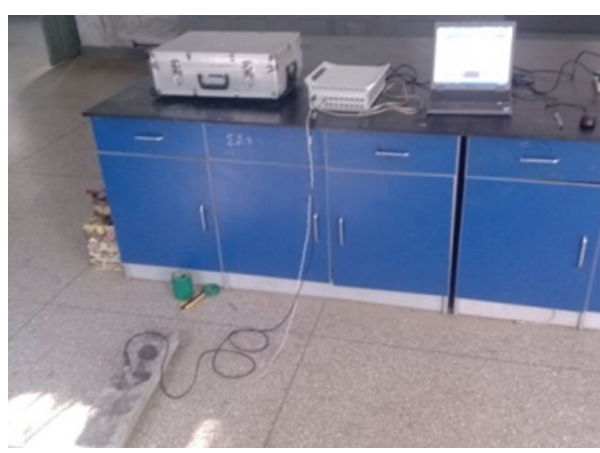

(b) Frequency test

FIGURE 11: Testing arrangement of frequency.

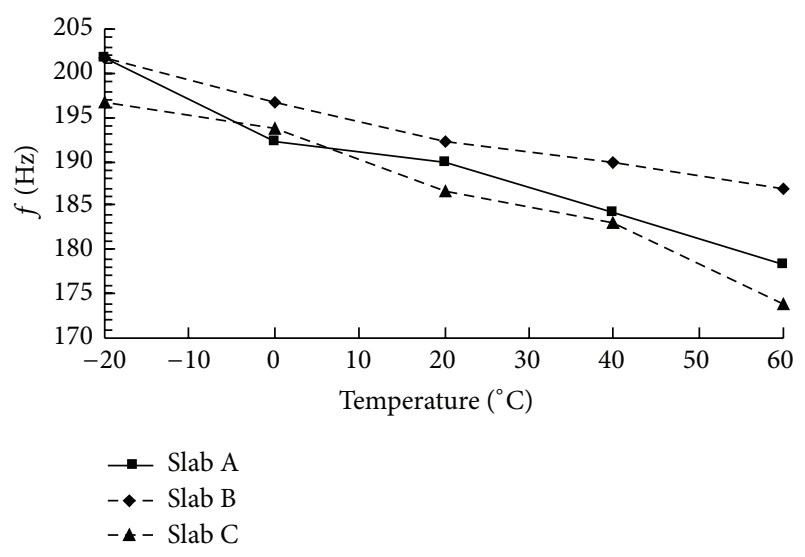

FIgURE 12: Temperature effect on first order natural frequency.

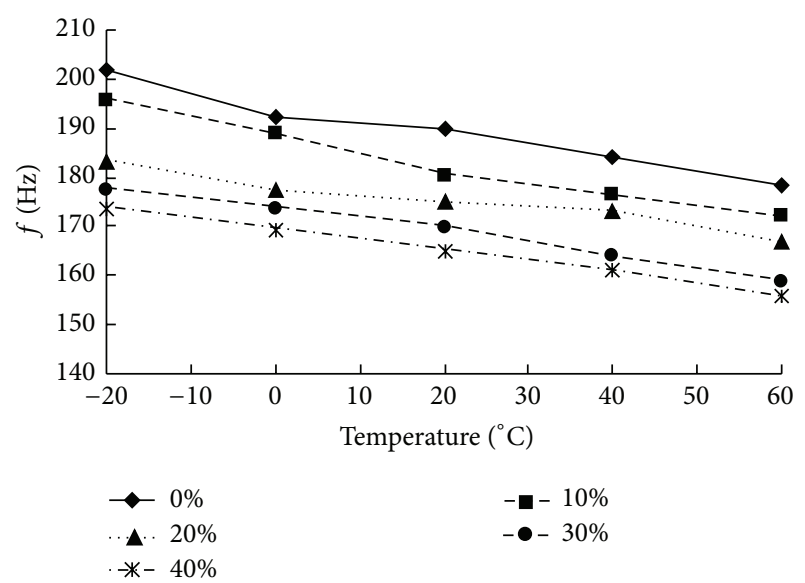

FIGURE 13: Integrated effect of temperature and damage on the first order natural frequency.

As can be seen from Table 8 and Figure 15, the calculated frequencies based on measured modulus of elasticity and dynamic theory are consistent with the measured ones. The results indicate that temperature effect on frequency is mainly caused by the influence of temperature on modulus of

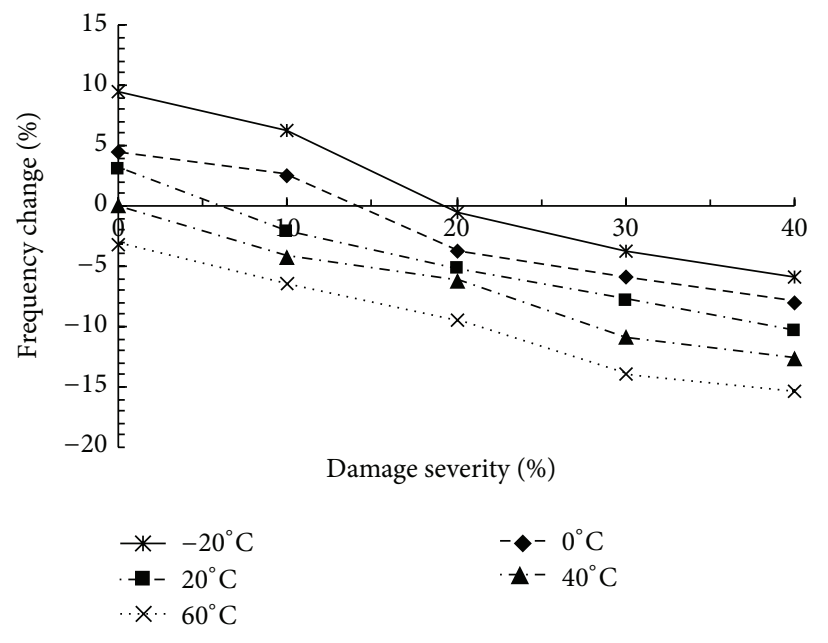

FIGURE 14: Integrated effect of temperature and damage on change rate of natural frequency.

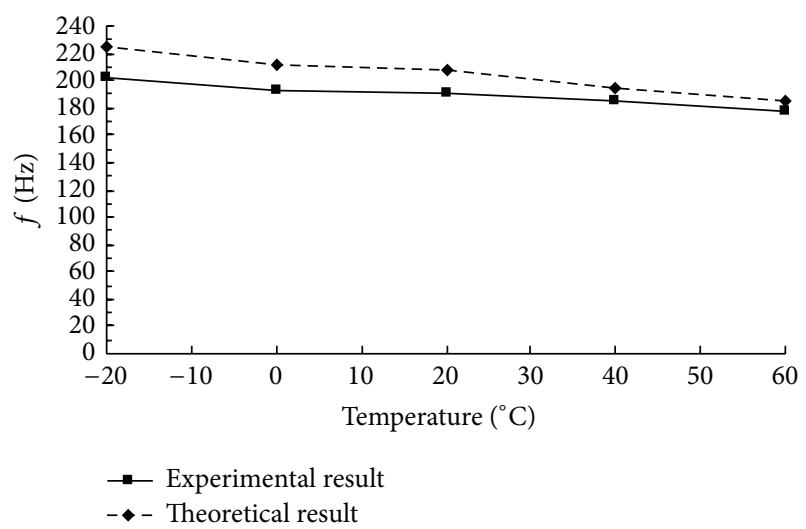

FIGURE 15: Relationship between theoretical and measured frequency of concrete slab.

elasticity. It can provide reference for damage identification of structures. 


\section{Conclusions}

Temperature effects on cube compressive strength, splitting tensile strength, prism compressive strength, modulus of elasticity, and frequency are conducted and the following conclusions can be drawn.

(1) Compressive strength (cube and prism), splitting tensile strength, and modulus of elasticity change obviously under temperature effect. These static mechanical properties all decrease with the increasing of temperature, and linear formulas can effectively simulate their relationships. The compressive strength improves by $100.3 \%$ from $60^{\circ} \mathrm{C}$ to $-20^{\circ} \mathrm{C}$; it is $132.9 \%$ and $48.3 \%$ for splitting tensile strength and modulus of elasticity, respectively.

(2) Influence of temperature on the first order frequency of concrete slab is significant and the frequency decreases with the increasing of temperature; a good negative relationship is present. Under the coupling effect of damage and temperature, the frequency change caused by damage would be submerged by temperature effect. Therefore, it is necessary to consider the influence of temperature in damage identification of structure. The range analysis reveals that the temperature effect cannot be neglected in practice. Mechanism analysis of temperature effect on frequency is also conducted. The results demonstrated that it is mainly caused by the influence of temperature on modulus of elasticity.

\section{Conflict of Interests}

The authors declare that there is no conflict of interests regarding the publication of this paper.

\section{Acknowledgments}

The authors express their appreciation for the financial support of the National Natural Science Foundation of China under Grant nos. 51408258, 51378236, and 51278222; China Postdoctoral Science Foundation that funded the project (2014M560237); and the Fundamental Research Funds for the Central Universities and Science \& Technology Development Program of Jilin Province (20140203002SF).

\section{References}

[1] L. Biolzi, G. Di Luzio, and J. F. Labuz, "Mechanical properties of photocatalytic white concrete subjected to high temperatures," Cement and Concrete Composites, vol. 39, pp. 73-81, 2013.

[2] W. Khaliq and V. Kodur, "Thermal and mechanical properties of fiber reinforced high performance self-consolidating concrete at elevated temperatures," Cement and Concrete Research, vol. 41, no. 11, pp. 1112-1122, 2011.

[3] G.-F. Peng, W.-W. Yang, J. Zhao, Y.-F. Liu, S.-H. Bian, and L.-H. Zhao, "Explosive spalling and residual mechanical properties of fiber-toughened high-performance concrete subjected to high temperatures," Cement and Concrete Research, vol. 36, no. 4, pp. 723-727, 2006.
[4] M. S. Cülfik and T. Özturan, "Mechanical properties of normal and high strength concretes subjected to high temperatures and using image analysis to detect bond deteriorations," Construction and Building Materials, vol. 24, no. 8, pp. 1486-1493, 2010.

[5] H. Fares, A. Noumowe, and S. Remond, "Self-consolidating concrete subjected to high temperature. Mechanical and physicochemical properties," Cement and Concrete Research, vol. 39, no. 12, pp. 1230-1238, 2009.

[6] S. N. Shoukry, G. W. William, B. Downie, and M. Y. Riad, "Effect of moisture and temperature on the mechanical properties of concrete," Construction and Building Materials, vol. 25, no. 2, pp. 688-696, 2011.

[7] J. Xiang, T. Matsumoto, Y. Wang, and Z. Jiang, "Detect damages in conical shells using curvature mode shape and wavelet finite element method," International Journal of Mechanical Sciences, vol. 66, pp. 83-93, 2013.

[8] J.-W. Xiang, T. Matsumoto, J.-Q. Long, and G. Ma, "Identification of damage locations based on operating deflection shape," Nondestructive Testing and Evaluation, vol. 28, no. 2, pp. 166180,2013

[9] J. W. Xiang, U. Nackenhorst, Y. X. Wang, Y. Y. Jiang, H. F. Gao, and Y. M. He, "A new method to detect cracks in plate-like structures with though-thickness cracks," Smart Structures and Systems, vol. 14, no. 3, pp. 397-418, 2014.

[10] K. Dems and Z. Mróz, "Damage identification using modal, static and thermographic analysis with additional control parameters," Computers and Structures, vol. 88, no. 21-22, pp. 12541264,2010

[11] S. W. Doebling, C. R. Farrar, and M. B. Prime, "A review of damage identification methods that examine changes in dynamic properties," Shock and Vibration Digest, vol. 30, no. 2, pp. 91-105, 1998.

[12] H.-P. Chen, "Application of regularization methods to damage detection in large scale plane frame structures using incomplete noisy modal data," Engineering Structures, vol. 30, no. 11, pp. $3219-3227,2008$

[13] J.-T. Kim, J.-H. Park, and B.-J. Lee, "Vibration-based damage monitoring in model plate-girder bridges under uncertain temperature conditions," Engineering Structures, vol. 29, no. 7, pp. 1354-1365, 2007.

[14] C. Farrar, S. Doebling, P. Cornell, and E. Starser, "Variability of modal parameters measured on the Alamosa Canyon bridge," in 15th International Modal Analysis Conference, vol. 3089 of Proceedings of SPIE, pp. 257-263, 1997.

[15] V. Askegaard and P. Mossing, "Long term observation of RCbridge using changes in natural frequency," Nordic Concrete Research, vol. 7, pp. 20-27, 1988.

[16] M. A. Wahab and G. de Roeck, "Effect of temperature on dynamic system parameters of a highway bridge," Structural Engineering International, vol. 7, no. 4, pp. 266-270, 1997.

[17] P. Moser and B. Moaveni, "Environmental effects on the identified natural frequencies of the Dowling Hall Footbridge," Mechanical Systems and Signal Processing, vol. 25, no. 7, pp. 23362357, 2011.

[18] GB175-2007, National Standard of the People's Republic of China, Common Portland Cement, 2007 (Chinese).

[19] National Standard of the People's Republic of China, "Standard for test method of mechanical properties on ordinary concrete" (Chinese), GB/T 50081-2002, 2003.

[20] GB 50164-2011, National Standard of the People's Republic of China. Standard for Quality Control of Concrete, 2011, (Chinese). 
[21] GB/T 50082-2009, Standard for Test Methods of Long-Term Performance and Durability of Ordinary Concrete, National Standard of the People's Republic of China, 2009 (Chinese).

[22] R. D. Adams, P. Cawley, C. J. Pye, and B. J. Stone, "A vibration technique for nondestructively assessing the integrity of structures," Journal of Mechanical Engineering Science, vol. 20, no. 2, pp. 93-100, 1978.

[23] R. Clough and J. Penzien, Dynamics of Structures, Prentice Hall, Upper Saddle River, NJ, USA, 2006.

[24] Y. Xia, H. Hao, G. Zanardo, and A. Deeks, "Long term vibration monitoring of an RC slab: temperature and humidity effect," Engineering Structures, vol. 28, no. 3, pp. 441-452, 2006. 

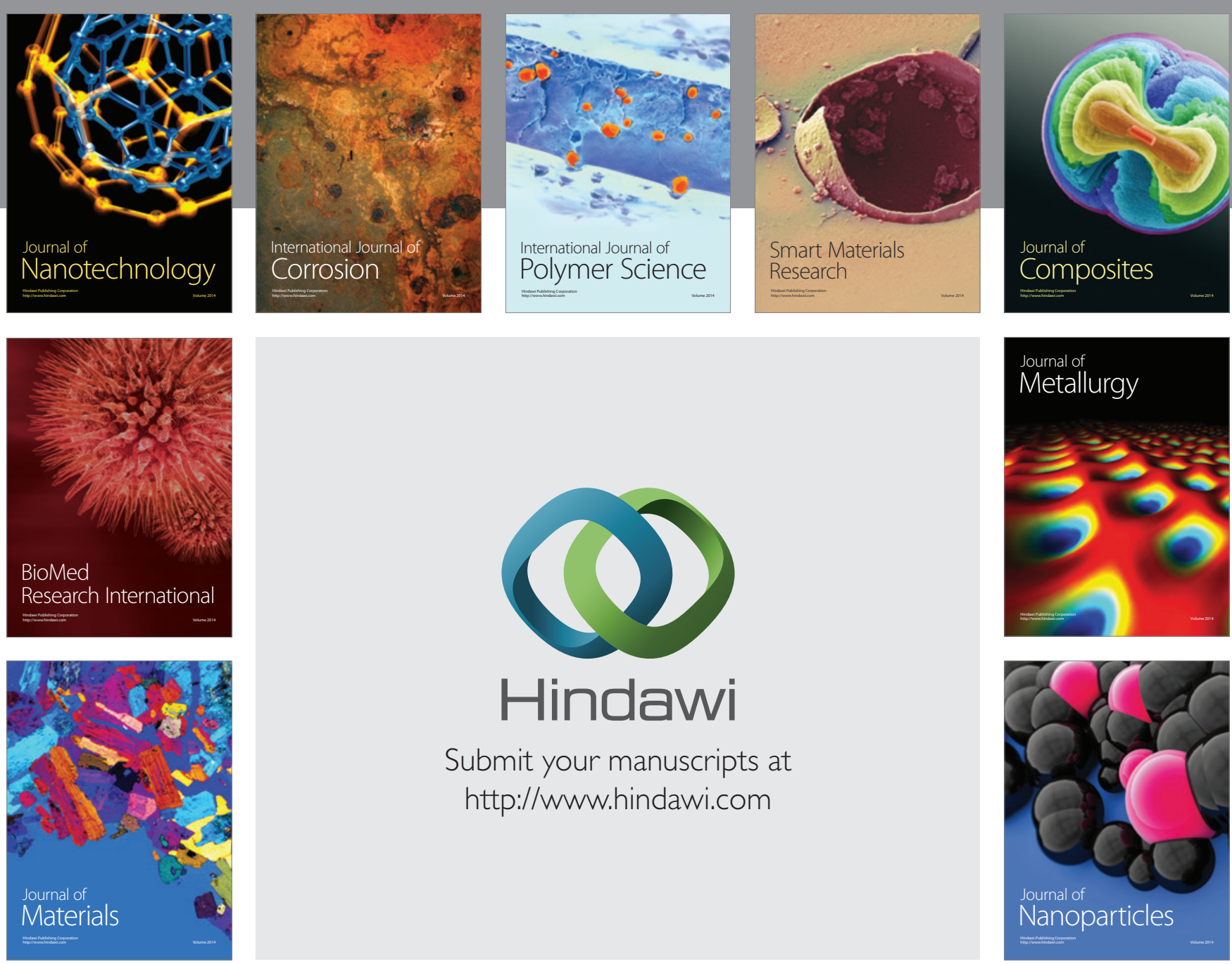

Submit your manuscripts at http://www.hindawi.com
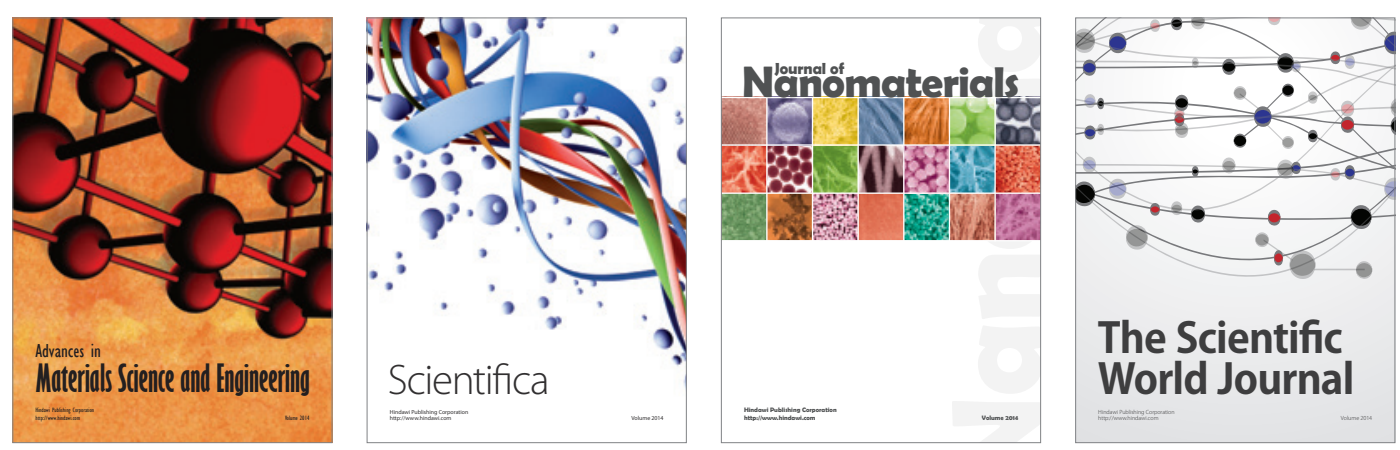

\section{The Scientific World Journal}
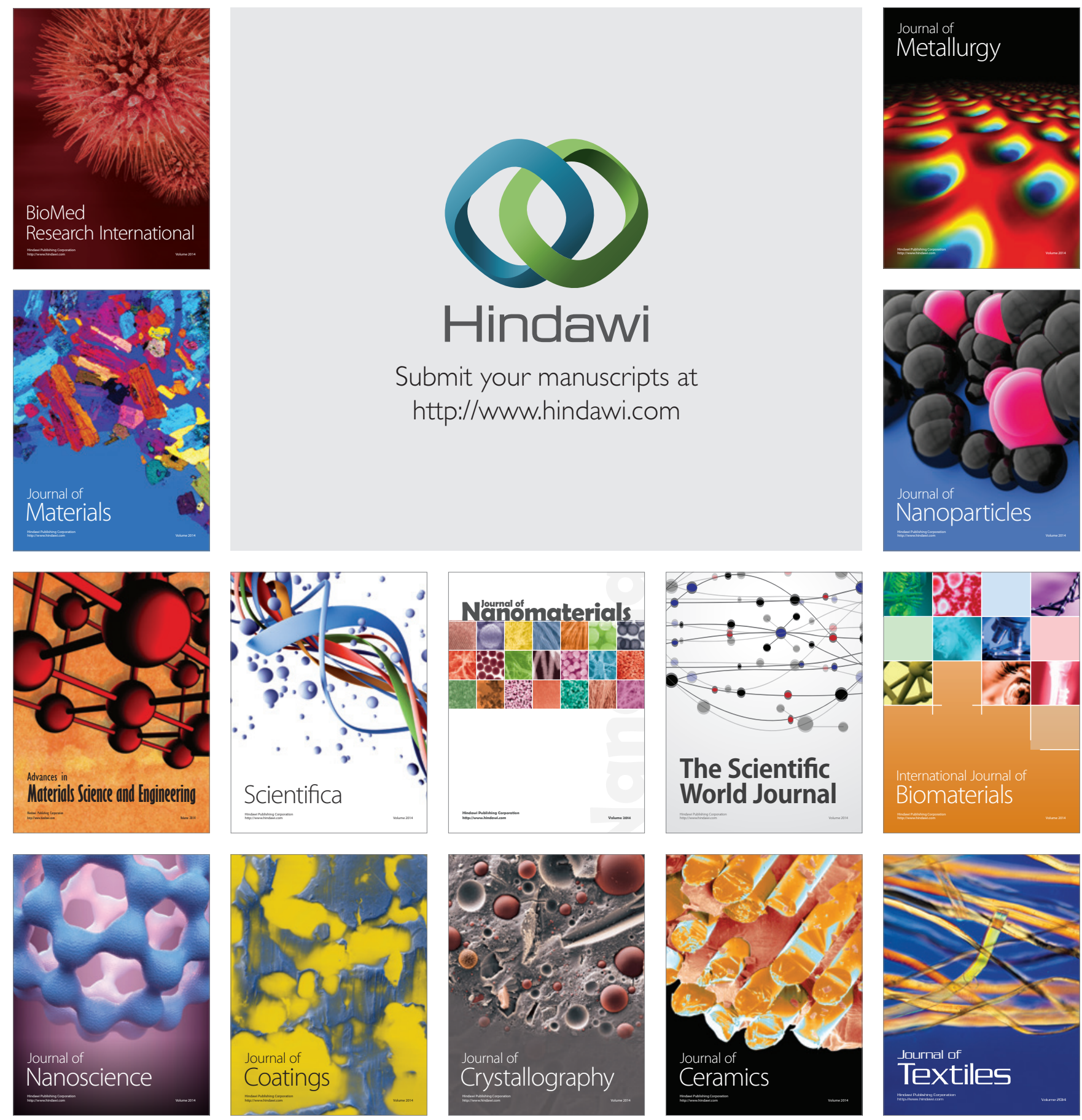